\title{
NDT assessment of timber structures: a case study - Villa Ivonne, Meliana
}

\author{
L. Palaia ${ }^{1}$, S. Tormo ${ }^{1}$, V. López ${ }^{1} \&$ J. Monfort ${ }^{2}$ \\ ${ }^{1}$ Building Construction Department, Escuela Técnica Superior de \\ Arquitectura, Universidad Politécnica de Valencia, Spain \\ ${ }^{2}$ Structures Department, Escuela Técnica Superior de Arquitectura, \\ Universidad Politécnica de Valencia, Spain
}

\begin{abstract}
Conservation of historic buildings demands a special assessment method to ensure there is no damage to the existing structures. This concept must be adopted by all architects, engineers and technicians involved in historic building conservation.

Floor and roof timber construction was widely extended in the vernacular buildings at Valencia. Floors were built usually by using timber joists, separated at $70 \mathrm{~cm}$ each, and with brick vaults between them. Timber roof structures consisted of rafters and rows for pitched roofs, with slopes inferior to $30^{\circ}$.

A research group at the Polytechnic University of Valencia [1] has developed a NDT method of assessment of timber structures applied to the historic heritage. "Villa Ivonne", a traditional building located at Meliana, close to Valencia (Spain) with timber roofs. It was used as a case study in which this method of assessment was applied. Besides the NDT measurements, visual inspection was done and its building timber structure system and pathology was studied. In this paper the NDT method is presented, by using ultrasonic, micro drilling and wood hardener devices. From the conclusions of these studies, pathology causes can be identified, and the subsequent repairs can be proposed.
\end{abstract}

Keywords: building conservation, timber structures, NDT assessments.

\section{Introduction}

Building conservation involves a wide range of approaches. The term "conservation" may be defined as the process of protecting a building and its 
surroundings from any change that might involve a loss of historic fabric, historic importance or character [2]. Most buildings have an active function, they are in use, or they were built for a proper use, that later may change. Changes of its original use may preserve its further decay, or on the contrary, produce serious damage to their structures. Otherwise these buildings can be abandoned and destroyed by ageing.

When working with historic buildings and structures it is important that the architects and other technicians approach with a proven methodology, making sure not to obviate any part of the information that is required for its complete knowledge. There are many structural elements and their relationships to deal with in order to know the building development and preserving their essential parts considered as a unity. Several disciplines must be involved in this process. All technicians must be trained in building conservation in order to have similar sensibility to the building approach. Together with this problem there is another one: the modern loading codes applied to historic structures. These must be attained, but always in a respectful way, trying to find a compatible solution.

Historical aspects of the building must be understood, and the conservation proposal must be undertaken with consensus. Working with timber structures, specialists on its conservation have to be invited to the surveying teams. Timber is the most variable of materials. Different wood species can be found in a building; its jointing, its decay, the loads transfer from one element to another; all these aspects have different levels of variability.

Research is essential for all types of timber structures, even the most unpretentious ones. The authors of this paper belong to an interdisciplinary research group, created in order to evaluate the efficiency of different destructive techniques and non destructive methods applied to the analysis and diagnosis of ancient buildings, attending to three main aspects:

- Evaluation of different methods for ancient building assessment including NDT ones.

- Comparison between the data coming out from the diverse NDT instruments applied and traditional methods, looking for correlations between them.

- Establishment of a procedure to apply for ancient building assessment, allowing organizing and systematizing the previous studies necessary for planning the conservation process.

In this case, the results of timber structure diagnosis of an interesting building, Villa Ivonne, are presented. A methodology of diagnosis to undertake this sort of survey was prepared in order to give accurate results, shortening time consuming tasks, applying a reduced number of instrumental measures, avoiding a massive destructive testing at the Laboratory.

\section{2 "Villa Ivonne", the Nolla palace: brief history, construction system and current conservation status}

This building is located at the "Camí del Barranquet", known as the Nolla neighbourhood, belonging to Meliana municipality. This is an orchard area, 
which is close to the old Nolla factory, currently occupied by the company Merlin Gerin Gardy, SA, since the 80s of the last century [3]. This two storey building with a lumber room, has a main body and a number of outbuildings, such as a front porch and a service area at its back, with a pitched roof, being topped by a tower with a hemispherical dome (Figures 1 and 2).

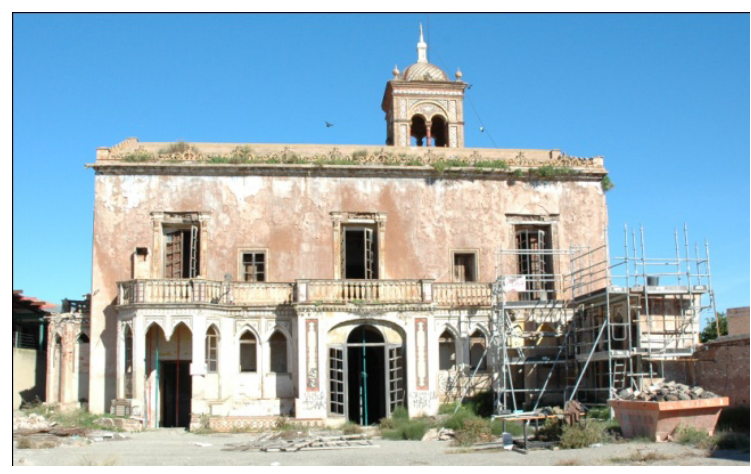

Figure 1: Villa Ivonne. Principal façade.

The house was linked to the prestigious Nolla factory dedicated to produce small-sized hydraulic tiles with various designs, to be used as pavements and wall mosaic. It was founded by Miguel Nolla Bruixet in 1862, occupying a very long farm known as the "Alquería of Gall," Alquería of Tramuser "or "Alquería de los Frailes ", depending on different authors. Its origin is therefore close to that date, when the company's owner created a recreational village, located near the industrial complex, with a garden setting, and provided with the best possible conditions at the time (Figure 2). The "villa" was built using the pre-existence of a farm type building as mentioned above, probably of the late 15th and early 16th centuries, which is apparent from some of the remains, as carved stonework arches and reinforcements on the corners with pilasters and capitals of classical influence (Figure 3). However, the appearance of the building shows the

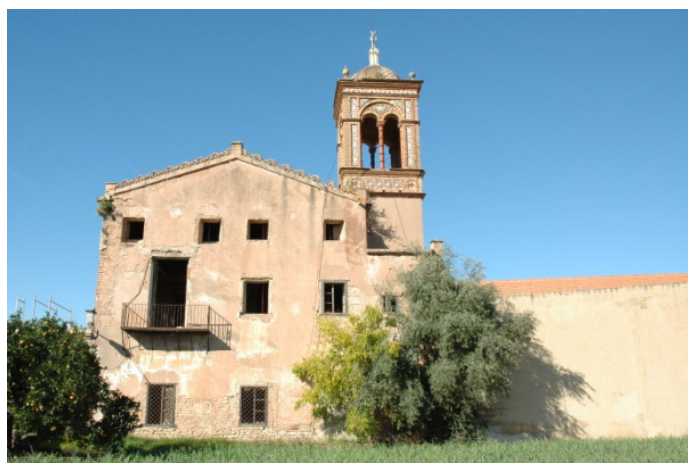

Figure 2: Villa Ivonne. Lateral façade. 


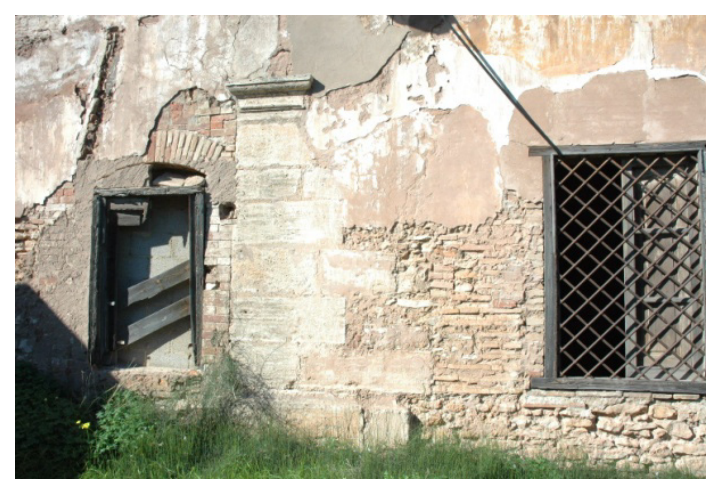

Figure 3: $\quad$ Pilasters and capitals of classical influence.

aesthetic of major renovations and expansion done in the $2^{\text {nd }}$ half of the $19^{\text {th }}$ century, with the extensive use of materials from Nolla's company, being its main interest.

In 1916 the property was acquired by the family of Ivonne Volozan, hence the name later was assigned to the building. From that date until 1968, when it was abandoned, renovation and interior fittings were done, but not materially changed the building aesthetically. The subsequent transfer of property to be acquired by the company Gardy SA along with the rest of the industrial plant, gradually led to its decline and subsequent abandonment, having lost its residential character, eliminating the gardens of the environment for expansion of industrial buildings, used as a warehouse or loading area. The building was finally acquired by the Municipality of Meliana, building a fence separating it from the industrial complex. Nowadays it has no use. In several times, the town council tried to undertake mayor research works in order to prepare a conservation project.

\subsection{Architectural and historical value}

The main building historical values are in relation with the old factory Nolla, and of course its unique stylistic character in keeping with the eclectic historicism of that time, in this case mix of neo-medieval and neo-mudejar, combined with classic style.

The building has thick masonry walls with reinforced corners of stone and brick walls. Hollow bricks were used in the most recent additions and refurbishments. It is extensively decorated with Nolla mosaics of different sizes and patterns, both the pavements and the interior and exterior vertical surfaces. Also noteworthy is the decoration done with murals, plaster work and joinery work in various areas, notably in access, main rooms and bedrooms. 


\subsection{About the construction system}

As most of the traditional buildings built at Valencia before the industrial revolution, they have brick, masonry or "tapial" walls as the vertical structure. Timber is used as structural material for floors and roofs. Floor structure is usually formed by timber joists, with brick vaults in between. Over this structure there is an earth and small stones filling, to prepare a good levelled surface to fix the pavements, Nolla pieces in this case. The pitched roof structure consists of timber rafters measuring $10-12$ by $20-22 \mathrm{~cm}$ separated by about $65 \mathrm{~cm}$ to each and other and bearing directly on the exterior and central walls, defining two aisles, north 4.62 wide and south $4.7 \mathrm{~m}$ wide. A secondary system is transversally disposed to the former ones, measuring 3,5 by $8 \mathrm{~cm}$ separated by $30 \mathrm{~cm}$, and between those, bricks $(14,5 \times 30 \mathrm{~cm})$ are laid forming the board to support the curved tiles (Figure $4 \mathrm{a}$ and b). Historically, the timber used at Valencia area was pinus sylvestris, because of its availability.

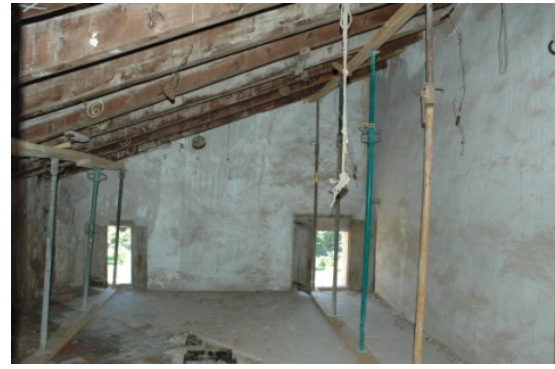

a)

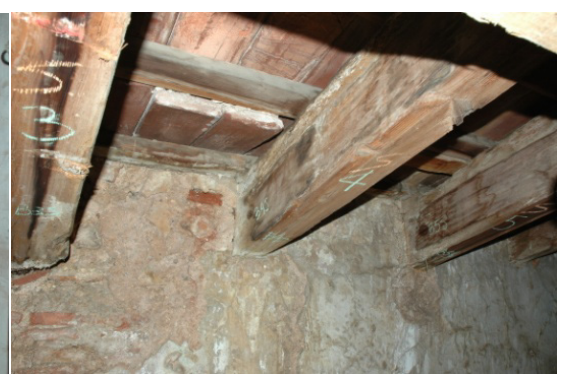

b)

Figure 4: a) General view of the roof structure, b) a detail of the roof structure.

\subsection{Its current conservation status}

Its general condition is very impaired, having produced partial collapses in some areas. There has also been dismantling and uncontrolled stack of some coatings, and in some cases has suffered vandalism actions. All this has led to propose a series of studies on the building and intervention projects, which to date have not been able to be carried out. Preventive actions such as cleaning, shoring and removal of those elements that had a higher risk of collapse has been the only works done. As a conclusion of the aspects mentioned above, mortar coatings of exterior walls and carpentry are seriously damaged, and roof leaks have allowed water to reach timber elements producing wood rot and other biological attacks.

\section{Methodology of the surveying process}

In Table 1: Methodology of the surveying process, there is shown the methodology for timber structures surveying after some experience was achieved in this type of works, which was proposed by the mentioned research group. 
Table 1: $\quad$ Methodology of the surveying process.

\begin{tabular}{|c|c|c|}
\hline Phase & Works to be done/NDT device & Data obtained \\
\hline \multirow{3}{*}{$\begin{array}{l}\text { Building } \\
\text { general } \\
\text { aspects } \\
\text { definition }\end{array}$} & $\begin{array}{l}\text { Compilation of historic } \\
\text { documental/graphic information }\end{array}$ & $\begin{array}{l}\text { Original configuration, repairs, } \\
\text { refurbishments and enlarging } \\
\text { process }\end{array}$ \\
\hline & Analysis of this information & $\begin{array}{l}\text { Building type and construction } \\
\text { system identification }\end{array}$ \\
\hline & $\begin{array}{l}\text { Visual detection of pathological } \\
\text { areas }\end{array}$ & Problems detection \\
\hline \multirow[t]{4}{*}{$\begin{array}{l}\text { Graphic } \\
\text { analysis }\end{array}$} & $\begin{array}{l}\text { General planning for the onsite } \\
\text { data gathering }\end{array}$ & \multirow{2}{*}{$\begin{array}{l}\text { Points of view and supporting } \\
\text { points. Selection for captured } \\
\text { images for metric rectification. }\end{array}$} \\
\hline & $\begin{array}{l}\text { High resolution digital images } \\
\text { capture }\end{array}$ & \\
\hline & $\begin{array}{l}\text { Building general layout. } \\
\text { Sketches of construction system }\end{array}$ & $\begin{array}{l}\text { Plans, sections and elevations } \\
\text { drawings. } \\
\text { Construction system and building } \\
\text { materials identification. }\end{array}$ \\
\hline & Metric rectified images analysis & General pathology identification \\
\hline \multirow[t]{3}{*}{$\begin{array}{l}\text { Timber } \\
\text { analysis }\end{array}$} & $\begin{array}{l}\text { General structure and jointing } \\
\text { analysis. Timber elements } \\
\text { identification. }\end{array}$ & $\begin{array}{l}\text { Structure description, geometry. } \\
\text { Preparation of timber elements } \\
\text { record cards }\end{array}$ \\
\hline & Visual inspection & $\begin{array}{l}\text { Defects, decayed areas detection. } \\
\text { Timber structural quality } \\
\text { definition }\end{array}$ \\
\hline & $\begin{array}{l}\text { NDT devices: Hygrometer, } \\
\text { ultrasonic, micro-drilling and } \\
\text { wood hardener. }\end{array}$ & $\begin{array}{l}\text { Moisture content measurement, } \\
\text { MOE approximation, density, } \\
\text { external consistency, internal } \\
\text { observation of the element. } \\
\text { Conclusions. }\end{array}$ \\
\hline \multirow[t]{3}{*}{ Final report } & $\begin{array}{l}\text { Compilation of all data and } \\
\text { conclusions of different phases }\end{array}$ & $\begin{array}{l}\text { General conclusions of the } \\
\text { different methods applied }\end{array}$ \\
\hline & Data and results presentation & Information summarize \\
\hline & General conclusions & Proposals for repairs \\
\hline
\end{tabular}

\subsection{Visual inspection and NDT devices}

Timber structures may be decayed by root and insect attack. Many inspections were made by this research group for timber structure assessment, employing traditional methods besides a hygrometer, ultrasonic, wood hardener (Pilodyn) testing with proved references about its viability [4-7] and a micro-drilling device, Rinntech 3450 [8-12], as NDT methods applied to evaluate the timber structure.

Visual inspection must be the first step to do for the data compilation of each timber element. Record cards were done for each rafter, previously identified with a proper code, including all the information obtained on site: sizes of the square sections, moisture content, spices, defects, grain deviation, number of knots and its size in reference to the face in which those are contained, decay, 
and other characteristics that are necessary for defining the structural quality of timber elements and its decay.

Afterwards the NDT was applied, as follows (Figure 5):

- Ultrasonics, to make an approach to the MOE (Dynamic MOE was obtained, being the static MOE $95 \%$ of that value for the spice cited before), of all elements.

- Wood hardener tester, to determine surface consistency (alterations, density), of all elements

- Microdrilling, to give a "view" of the timber element interior, one each three and in all elements where alterations were detected

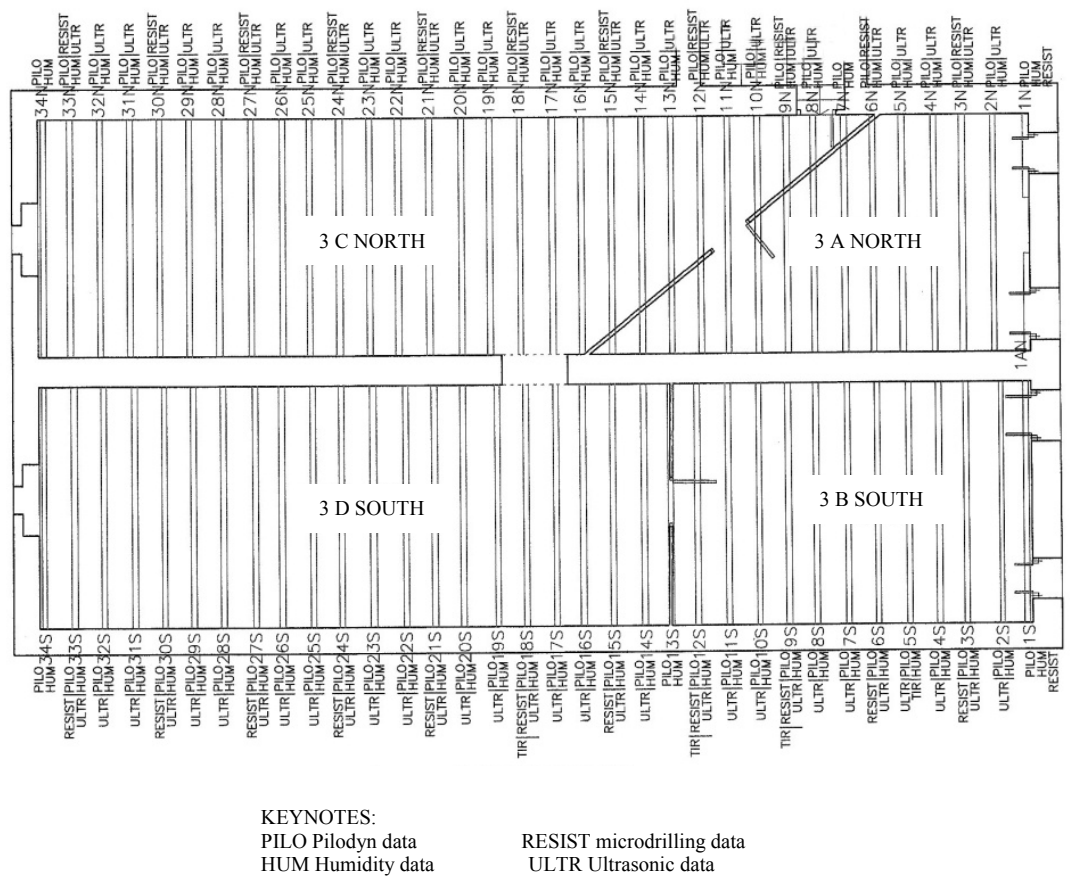

Figure 5: General plan of the roof structure, with indication of the NDT testing.

\section{The results}

The results of this surveying must be presented separately: those coming from the visual inspection and those obtained by NDT devices [13]. In order to minimize the information given about the results, there will be only shown in this paper those obtained at rafter's lower end (north) of room " $\mathrm{A}$ ", 3 rd level. 


\subsection{Visual inspection}

The data of visual inspection was registered by using a specific code to identify each timber element, as floor number, room name, element number, and end (north or south in this case). Sketches of each cross section were done, drawing the damaged areas and its extension, with one (or more) photographs showing its condition (Figure 6). The results of visual inspection were drawn in the roof plan.

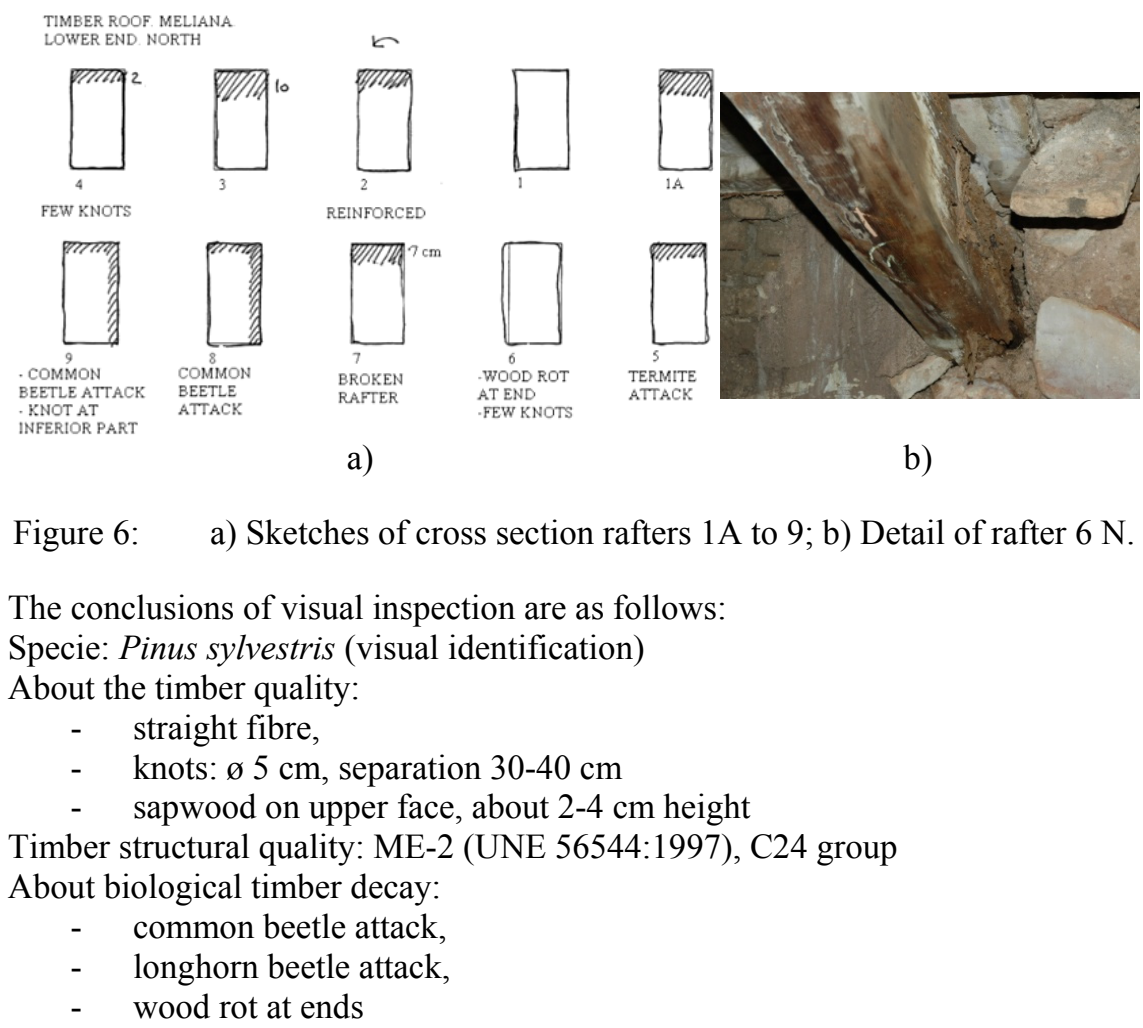

\subsection{NDT devices}

Ultrasonics, wood hardener tester and micro-drilling were the NDT devices applied for the diagnosis. The humidity content was also tested by means of a hygrometer.

\subsubsection{Ultrasonic testing}

As given before, ultrasonic testing allowed defining of the Dynamic MOE. Considering axial velocity value and its density, Dynamic MOE is 7,468068 $\mathrm{kN} / \mathrm{mm}^{2}$. The result was that the timber used for the structure construction was rather poor, in reference to its mechanical resistance (Table 2. Ultrasonic data). 
Table 2: $\quad$ Ultrasonic data.

ROOM 3A ROOM 3 A NORTH

\begin{tabular}{|c|c|c|c|c|c|c|}
\hline \multirow{3}{*}{$\begin{array}{c}\text { WIDTH } \\
\text { (cm) }\end{array}$} & \multirow{3}{*}{\begin{tabular}{|l} 
ULTRASONIC $(\mu \mathrm{s})$ \\
AT $5 \mathrm{~cm}$ TO WALL
\end{tabular}} & \multirow{3}{*}{ TG VELOCITY } & \multirow{2}{*}{\multicolumn{4}{|c|}{ MEDIA VALUES }} \\
\hline & & & & & & \\
\hline & & & $\begin{array}{c}\text { TG } \\
\text { VELOCITY }\end{array}$ & $\begin{array}{c}\text { AXIAL } \\
\text { VELOCITY }\end{array}$ & $\begin{array}{c}\text { DENSITY } \\
\mathrm{kg} / \mathrm{m}^{3}\end{array}$ & MOE $\mathrm{kN} / \mathrm{mm}^{2}$ \\
\hline \multirow{2}{*}{$\begin{array}{l}10 \\
12\end{array}$} & 63,5 & 1574,80315 & 1891,98 & 4729,95 & 320 & 7,468068 \\
\hline & 64,5 & 1860,465116 & & & & \\
\hline 11 & 53,5 & 2056,074766 & & & & \\
\hline \multirow{2}{*}{$\begin{array}{c}12 \\
10,5\end{array}$} & 67,1 & 1788,375559 & & & & \\
\hline & 52,9 & 1984,877127 & & & & \\
\hline 11 & 52,7 & 2087,286528 & & & & \\
\hline
\end{tabular}

\subsubsection{Wood hardener (Pilodyn)}

Pilodyn data was combined for its analysis with the results of visual inspection. There is a coincidence of higher values of Pilodyn testing results (greater pin penetration) in sapwood areas (upper part) and decayed parts of the rafters. Prospection was done as shown in sketches seen in Figure 7, and the results are in Table 3: humidity content, rafters square section, Pilodyn testing and comments of visual inspection.

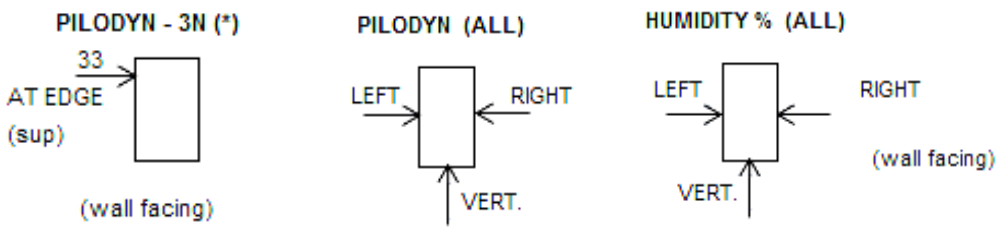

Figure 7: $\quad$ Sketches of prospection done by hygrometer and pilodyn testing.

Table 3: Humidity content, Pilodyn testing and comments of visual inspection.

\begin{tabular}{|c|c|c|c|c|c|c|c|c|c|c|c|c|c|}
\hline \multirow{3}{*}{ ROOM } & \multirow{3}{*}{ RAFTER } & \multicolumn{4}{|c|}{ HUMIDITY \% } & \multirow{3}{*}{$\begin{array}{c}\text { WIDTH } \\
(\mathrm{cm})\end{array}$} & \multicolumn{5}{|c|}{ PILODYN (AT END) } & \multirow{2}{*}{\multicolumn{2}{|c|}{ COMMENTS }} \\
\hline & & \multicolumn{3}{|c|}{ END } & \multirow{2}{*}{$\begin{array}{l}\text { VERT } \\
\text { (AT }\end{array}$} & & \multirow{2}{*}{$\begin{array}{c}\text { HEIGH } \\
(\mathrm{cm})\end{array}$} & \multirow{2}{*}{ VERT } & \multirow{2}{*}{ RIGHI } & \multirow[b]{2}{*}{ LEFI } & \multirow{2}{*}{$\begin{array}{c}\text { AT } \\
\text { EDG } \\
\end{array}$} & & \\
\hline & & VERT & IGH & EEFT & & & & & & & & UPPER END & LOWER END \\
\hline \multirow{9}{*}{$\begin{array}{l}3 \text { A } \\
\text { NORTH }\end{array}$} & $1 \mathrm{~A}(\mathrm{~N})$ & - & \begin{tabular}{|l}
- \\
\end{tabular} & \begin{tabular}{|l|}
- \\
\end{tabular} & - & 12 & 22 & - & - & - & - & & \\
\hline & $1 \mathrm{~N}$ & 24,6 & 25,3 & 23,8 & 14,2 & 12 & 20 & 10 & - & 15 & - & & \\
\hline & $2 \mathrm{~N}$ & 15,2 & 24,8 & 16 & 11,8 & 10 & 20 & 12 & 14 & 14 & - & $\begin{array}{l}\text { Metallic reinforcement in } 3 / 5 \text { its length } \\
\text { Twisted left }\end{array}$ & Twisted right \\
\hline & $3 \mathrm{~N}$ & 23,9 & 16,5 & 19,3 & 12,6 & 12 & 21,5 & 11 & 11,5 & 12 & $33(*)$ & & \\
\hline & $4 \mathrm{~N}$ & 21 & 22,5 & 19,1 & 13,1 & 11 & 22,5 & 11 & 13 & 13 & - & Few knots & \\
\hline & $5 \mathrm{~N}$ & 12,2 & 12 & 13,7 & 13,6 & 12 & 21 & 13,5 & 15 & 14 & $40(*)$ & $\begin{array}{l}\text { Many knots, each } 25 \mathrm{~cm} \text {. Very resinous } \\
\text { Termite attack }\end{array}$ & Twisted left \\
\hline & $6 \mathrm{~N}$ & 10,4 & 12,6 & 10,2 & 13,6 & 10,5 & 22,5 & 18 & 12 & 14 & - & Wood rot. Few knots & \\
\hline & $7 \mathrm{~N}$ & 14,9 & 12,7 & 12,2 & 13,9 & 12 & 21 & 12 & 16 & 17 & - & Broken & \\
\hline & $8 \mathrm{~N}$ & 13,8 & 14,8 & 16 & 13,1 & 11 & 22,5 & 13,5 & 14 & 17 & - & $\begin{array}{l}\text { Twisted left. Extended common beetle } \\
\text { attack }\end{array}$ & Twisted left \\
\hline
\end{tabular}


The Pilodyn values around 10 to 13 are considered as sound wood for this species. Higher values indicate that the timber is not in good condition. So, rafters $2 \mathrm{~N}, 3 \mathrm{~N}, 5 \mathrm{~N} 6 \mathrm{~N}, 7 \mathrm{~N}$ and $8 \mathrm{~N}$ present some decay or sapwood at the point where the testing was done. A correspondence with visual inspection results can be found (see figure 6a) and Table 3). High values of moisture content are indicating that there are water leaks in areas where rafters $1 \mathrm{~N}$ to $4 \mathrm{~N}$ are located, due to discontinuities in the cover material. This analysis was carried on with all rafters.

\subsubsection{Micro-drilling}

This testing allows having the internal view of the timber element. Graphs of two rafters, $3 \mathrm{~A}$ room, are included in this paper: $3 \mathrm{~N}$ and $6 \mathrm{~N}$ (Figures 8 and 9 respectively). The values of vertical axis belong to the engine force to maintain the same velocity of penetration of the $\varnothing 1,5 \mathrm{~mm}$ pin. Horizontal axis shows the position of the possible discontinuity of the rafter cross section, measured in centimeters. The first and the last centimeter of the graph should be rejected since it is due to the resistograph adjustment on the material. It is evident that on rafter $3 \mathrm{~N}$ there is a discontinuity at about $5 \mathrm{~cm}$ from its upper surface, where sapwood appears to be. In rafter $6 \mathrm{~N}$ there is no evidence of the wood rot at its

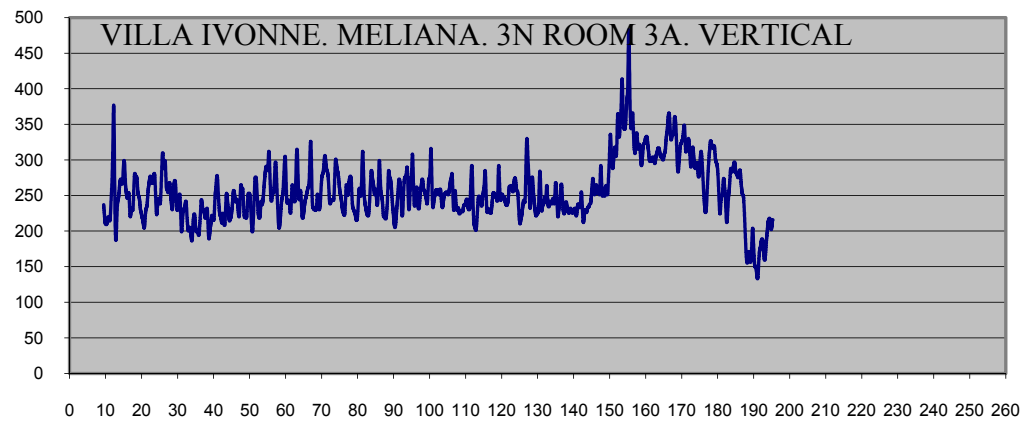

Figure 8: $\quad$ Microdrilling graphic of rafter 3N, vertical direction.

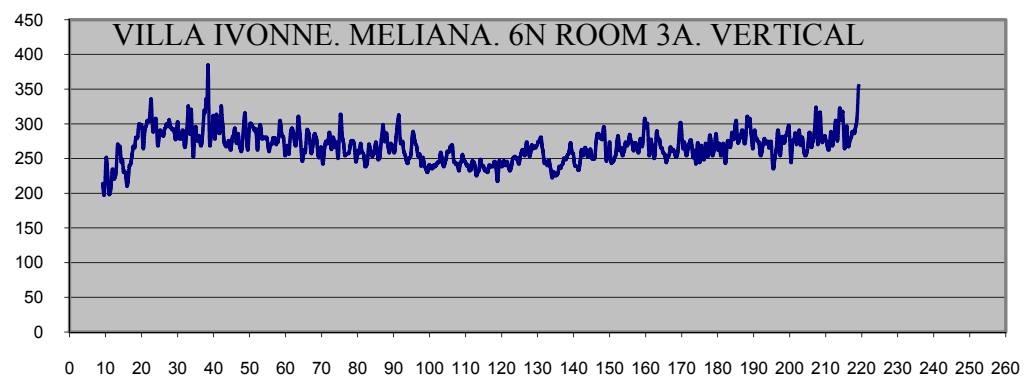

Figure 9: Microdrilling graphic of rafter $6 \mathrm{~N}$, vertical direction. 
end, as the resistograph was positioned at $25 \mathrm{~cm}$ to the wall. So, this decay is only localized at its end, where wood is in contact with wall materials.

Later, mean and maximum values of resistograph testing have been analyzed to overview the general structure mechanical properties.

\section{Conclusions}

Not only the material or individual element of wood has to be analyzed, but the whole structure, to give answers to the problems.

Experience shows that wood is usually found in good condition except for some detailed elements that are marked at the plans to be easily identified for its repair or replacement, as appropriate. Proposals for repair works are easily and straightforward elaborated.

Based on visual inspection, classification according to resistance class (UNE 56544:1997) may be determined and damaged areas detected.

Pilodyn testing values give an approximation to its density and consistency.

Resistograph printouts reveal what happens inside the elements, so that the damage extent can be determined.

The results of ultrasonic testing give an approximation to the $\mathrm{MOE}$, and from this data an analytical verification of its bearing capacity can be made.

Structural analysis of ancient wooden structures is possible when instruments are used to quantify the theoretical strength of the elements.

As the case study belongs to a roof structure in which bearing loads are not supposed to be increased after restoration works will be done, the recommendation is to repair damaged ends by means of epoxy resins and fiber glass bars as well as broken elements by using the same technique or eventually its substitution by new elements of same wood specie. Brick board must be repaired and tiles replaced, when necessary.

\section{References}

[1] The research group developed the project "NDT Methods of Ancient Buildings Assessment and Diagnosis of Building Materials and Construction Systems for its Conservation", financed by the Ministerio de Fomento2004-2007. This interdisciplinary group is formed by L. Palaia, J. Monfort, R. Sánchez, L. Gil, A. Álvarez, V. López, S. Tormo, C. Pérez and P. Navarro.

[2] Taylor, J., 10 Ways to Ruin an Old Building, Building Conservation, http://www.buildingconservation.com/

[3] Several bibliography was consulted about the building history: Herrero Fabregat, C., Geografía Agraria de Meliana, sin paginar, Valencia 1969; Barberá Nolla, M. R., Evocación de la Fábrica de Mosaicos Nolla, Publicación de la Cooperativa Eléctrica de Meliana en sus Bodas de Oro 1923-1973, Meliana 1973; Jordá, C., Del Rey, Gómis, A., M., MartínGonzález, M., Simó, T., Catáleg del Patrimoni arquitectónic de Meliana, Diputació Provincial de Valencia, 1986; Esteve Marco, J.J, Ferrer Orts, A., 
Mari Mulero, F. Navarro Santaclara, M.A., Villa Ivonne, Estudios Previos a su restauración y estado de la cuestión. IX Congreso de Conservación y Restauración de Bienes Culturales, Sevilla Septiembre de 1992; Lavara, N., Oficina Técnica Ayuntamiento de Meliana, Proyecto de "Trabajos previos fase 1 rehabilitación de Villa Ivonne, Diciembre de 2005; http://www.mosaiconolla.com/el-ayuntamiento-y-la-empresa-schneiderelectric-formalizan-la-cesion-del-'palauet-de-nolla'-25-anos-despuesnoticia-4-11.html; http://blogs.ya.com/palacionolla/

[4] Demaus, Robert, Non-Destructive Investigation, Buildingconservation.com, 1996

[5] Machado, "Strength appraisal of wooden members in service by combining new and old technology", Stremah 2007, WIT Press, 2007.

[6] Palaia, L., et al., La conservación de la madera en los edificios antiguos, Valencia, 1998.

[7] Bucur, V., Acoustics of wood, CRC, 1995

[8] Jorissen, André, "The Dutch Pavillion at the EXPO 2000 in Hannover".

[9] Giuliani, E, Gubana, A., Ensayo de penetración, para evaluar el deterioro de la madera, y su aplicación al monumento Loggia. Departamento de Ingeniería Civil, Universidad de Brescia, Vía Valotti 9, 25133 Brescia, Italia Materials and Structures, 1993, 26, 8-14

[10] Arriaga, F., Esteban, M., "Evaluation of load carrying capacity of old timber structures", Proceedings of the 8th Conference on Timber Engineering (WCTE 2004). Finnish Association of Civil Engineers (RIL), VTT Technical Research Centre of Finland and Wood Focus, Lahti, Finland 14-17 June 2004.

[11] Binda, L, Cantini, L., Condoleo \& Saisi A., "Non-destructive testing techniques applied to the masonry and timber structures of the Crocifisso Church in Noto", Stremah 2007, WIT Press, 2007

[12] Basterra, A. et al., Análisis de las técnicas de diagnóstico de madera estructural en edificios existentes y propuesta de integración orientada al proyecto, I Jornadas de investigación en construcción, Instituto de Ciencias de la Construcción "Eduardo Torroja"

[13] Part of these results were published at "Assessment of timber structures in service, by using combined methods of non-destructive testing together with traditional ones", authors L. Palaia, J. Monfort, R. Sánchez, L. Gil, A. Álvarez, V. López, S. Tormo, C. Pérez, P. Navarro, Art2008. 